\title{
The relationship between service level and mean operation time in technical assistance service: An empirical analysis of the queuing theory of a Peruvian cellphone company
}

\author{
Jose Luis Acero Chavez ${ }^{1}$, Teresa Longobardi Vergata² \\ 1 Universidad Ana G. Mendez, Rio Grande Road, Juncos, Gurabo, Puerto Rico \\ 2 Universidad de Puerto Rico, Av. Universidad 1401, San Juan, Puerto Rico \\ Enviado el 1 de diciembre del 2021. Aceptado el 9 de enero del 2022.
}

DOI: https://doi.org/10.33017/RevECIPeru2021.0012/

\section{Resumen}

Este trabajo presenta un análisis empírico entre dos de las variables más importantes para medir el desempeño del servicio de las operaciones de reparación de teléfonos celulares en una empresa peruana. El análisis se realiza bajo el marco de la teoría de colas para encontrar un modelo que se ajuste a los supuestos empíricos del sistema. Las limitaciones matemáticas se hacen evidentes cuando se estudia un problema real, específicamente en situaciones donde los supuestos básicos de las líneas de espera son demasiado simplistas y no son adecuados para trabajar con situaciones complejas como un centro de asistencia técnica de múltiples ubicaciones. Estudiamos si el Nivel de Servicio se ve afectado positiva o negativamente con el Tiempo Medio de Operación y si el número de agentes es un factor relevante. Utilizamos la técnica de simulación y datos reales de una empresa de telefonía celular en el Perú con múltiples ubicaciones en toda la ciudad de Lima. Los resultados muestran que existe una relación negativa entre las variables de estudio, con un nivel de confianza estadística del 95\%, siempre que el número de agentes sea menor a 6 para cualquier centro de atención.

Descriptores: Tiempo de servicio, Tiempo medio de operación, Centro de asistencia técnica, Teoría de colas, Simulación, compañía de telefonía celular.

\begin{abstract}
This paper presents an empirical analysis between two of the most important variables to measure the service performance of the operations of cell phone repair in a Peruvian company. The analysis is made under the Queuing Theory framework in order to find a model fitting with the empirical assumptions of the system. The mathematical limitations become evident when a real problem is studied, specifically in situations where the basic assumptions of the waiting lines are too simplistic and are not suitable to work with complex situation such as multiple location technical assistance centers. We study if the Level of Service is affected positively or negatively with the Mean Operation Time and if the number of agents is a relevant factor. We use the simulation technique and real data of a cellphone company in Peru with multiple locations throughout the city of Lima. The results show that there is a negative relationship between the variables of study at $95 \%$ of statistical confidence level, as long as the number of agents is less than 6 for every attention center.
\end{abstract}

Keywords: Service Level, Mean Operation Time, Technical Assistance Center, Queuing Theory, Simulation, cell phone company. 


\section{Introduction}

The performance of a Technical Assistance Center has become a critical issue in all channels of attention to customers. It is clear that the responsibility of a cellphone company does not end when this one sells the product, but it extends for the time the customer uses the cell phone and keep the line active. Every day more electronic products have shorter life cycles and cellphones are not the exception [1],[2]. Cellphones have an associated service which gives the products not only a guarantee of quality, but a high profitability for the company. consequently, the technical service area is important because assure the customer loyalty and support the continuity of the business [3]. Then, cellphones should be always in good operation conditions in the customer hands. In other words, if for some reason the customer's cellphone does not work, the company would lose money by forgone revenues. The latter generates that many cellphone companies subsidize the cost of the equipment and give their customers a high-quality technical service. The efficiency of a cellphone technical support system manifests through the speed with a technician solves a problem (Time Mean Operation), and the perception of quality service through service level indicator (Time that a customer waits in the queue). The design of this system is based on the Queuing Theory or Waiting Lines which has been extensively studied since 1909, when the Danish mathematician A. k. Erlang who applied it to the commutation of telephone lines [4]. There are different mathematical models to measure these parameters; basically, defined by the distribution of arrivals, the queue discipline and counter's service time. From these values you can get the required number of counters to serve customers [5],[2]. The solutions given by the mathematical models are practical when dealing with systems with a limited number of servers. When the configurations require a larger number of servers, and multiple location geographical distributed in a city, mathematical models become too complex or simply does not exist for practical purposes then the simulation technique offers a suitable approach [6],[7].

The operator plays an important role in both indicators LM and TMO when we have one operator

\section{Metodology}

the formulae are clear, the relationship is inversely proportional, the same happens with two operators, however this relation is no clear if we increase the numbers of operators [8]. TMO ranges from as low as one minute to as high as several hours. depending on the effectivity and efficiency of the operator and the location where he is working. It is important to note that low TMO does not ensure quality response or improve in SL indicator when we are dealing with a high number of operators. On the other hand, a low number of operators does not mean bad performance and a higher number of them does not mean otherwise. The findings of this study could be useful to understand how to assign efficiently the number of operators in the design of a technical system in such a way we get the best efficiency of the queue system of a cellphone company.

Hence it comes up a concern: How could reductions on the TMO (Mean Operation Time) impact on the SL (Service Level)? The mathematical formulas take to assume that the smaller the service time is the faster the server operators become; that is, less waiting time for customers and better efficiency [9]. Based on these considerations the following questions arise:

Is the relationship between the Service Level (SL) and the Mean Operation Time (TMO) inversely proportional in spite of the number of agents in a technical assistance center? What about learning from this relationship to improve operational performance and enhance customer's experience? The main target of this research is to demonstrate the negative relationship between SL and TMO considering the number of operators that are present in the system. From this supposition we can establish the following Hypothesis: $(\mathrm{H} 1)$ : There is a negative relationship between Level of Service (LS) and Mean Operation Time (TMO), the higher LS the lesser TMO. What happens with the number of operators and the degree of correlation?

The results, worked with real data, show that the hypothesis is valid for offices where there are numbers of operators lesser than 3 . As the number of operators increases the coefficient of correlation ( $r$ ) become strong. When work with the simulated data the hypothesis is valid for offices where there are less than 6 operators.

The present research takes an empirical perspective and a quantitative orientation to verify the Hypothesis and consequently the proposed relation 
between the variables under study. The data was gathered from the transactional system of the company under study which covers a period up to five months from each facility where it was possible to get the data from. A cross-sectional study was used.

The data comes from nine of twelve facilities that have the Customer Service area. It represents $75 \%$ from all facilities located in the city of Lima. The worked hours are showed in the Table 1, whereas the number of days and the registered accountants are showed in Table 2.

Table 1: List of offices with technical assistance and the number of worded hours. The start hour varies each according to different policies.

\begin{tabular}{lc}
\hline Offices & Worked hours \\
\hline San Miguel & 12 \\
Megaplaza & 12 \\
Lince & 9 \\
Juan de Arona & 10 \\
Camino Real & 9 \\
Jr. de la Union & 9 \\
Miraflores & 10 \\
San Juan de Miraflores & 9 \\
San Borja & 9 \\
\hline
\end{tabular}

The transactional data gathered is grouped by days, which means that the TMO and LS are calculated at the end of the day and that all the data registered with this date is taken into account in the calculation of the indicators.

Table 2: Characteristics of the Data sample used for analysis. The offices of technical centers are distributed throughout 9 locations in the city of Lima. The data spans from August to December.

\begin{tabular}{lcccc}
\hline Offices & $\begin{array}{c}\text { Start } \\
\text { data }\end{array}$ & $\begin{array}{c}\text { End } \\
\text { data }\end{array}$ & days & Records \\
\hline San Miguel & Ago & Dic & 15 & 1638 \\
Megaplaza & Ago & Sep & 12 & 1979 \\
Lince & Oct & Dic & 39 & 2931 \\
Juan de Arona & Ago & Oct & 33 & 5025 \\
Camino Real & Ago & Dic & 68 & 9156 \\
Jr. de la Union & Ago & Ago & 9 & 1084 \\
Miraflores & Ago & Nov & 45 & 5267 \\
S. J. de Miraflores & Oct & Nov & 14 & 356 \\
San Borja & Ago & Dic & 94 & 22855 \\
\hline Total & & & $\mathbf{3 2 9}$ & $\mathbf{5 0 2 9 1}$ \\
\hline
\end{tabular}

Table 2 groups all the values available per office and the total study period (max. 5 months). Setting two data sets in order to calculate the correlation of the two variables, one for the actual values and the other for the simulated ones. The reason for using a simulation model is to verify that the actual values are not influenced by other factors not considered in the cases, for example, if on a particular day there was a sickness absence of agents who could not be replaced (assuming that this is an extreme situation) and the system capacity was below the normal operation, then the system worked poorly. But the cause of this failure was due to an event of low probability of occurrence.

\subsection{Definition of Variables and terms}

Service Level (SL): Is one of the most important metrics in the customer service industry. It is known as the Average Speed of Answer (ASA) too. This measures the speed of response and is expressed as percentage of requests within target threshold. The goal is set based on customer expectations and sort of service. For example: 95\% / 15 means 95 attentions over 100 within 15 minutes. In the light of Queuing Theory this rate is related with $\mathrm{W}$ and $W_{q}$ which measure the time of customer in the system and in the queue. It is expressed as $\mu$.

Mean Operation Time (TMO): It is also known as Operating Time (OP), Average Handle Time (AHT) or Average Service Rate (ASR) It is the average time that takes an operator or agent to process a transaction. In a Technical Assistance Center, it includes tasks like talk time, solve the user's problems and complete the transaction after the end user has completed its participation in the transaction. In practical case is valid assume that TMO is the inverse of $\mu(1 / \mu)$

Technical Assistance Center (Technical Support or Service Desk): The service desk is the central point of contact between service providers and the users to report incidents and raise service requests.

Service desk agent (Operator, server or agent): is the person who provides the technical service to customers. His performance is evaluated through the TMO (individual) and LS (group).

\subsection{Queuing Model}

It was worked on this study with a real queuing system of a technical support area of a cellphone company in Peru. Together with the real data, it was validated through a simulation model the 
relationship under study, then it was confirmed the established hypothesis with two points of view. The values of the variables manage with empirical data and the simulation model was built with the queuing theoretical framework [9],[10],[11],[12] . The simulation model is adjusted to fit the best possible to reproduce the system under study and is considered the following characteristics, (see Figure 1):

(i) The arrival pattern of servers follows an empirical distribution. The impatient clients show a balked behavior, they look at the queue and then leave it, or it could happen that they are having a long wait and suddenly decide to abandon (reneged). It is considered that the pattern of arrivals changes through the workday, in other words, they are nonstationary. (ii) The service pattern alike the arrival pattern is described as an empirical distribution and presents non-stationary behavior. The dependence of the values of the TMO with the number of customers waiting in the system is possible, that is considered in the model. (iii) Queue discipline is FIFO (First in, First out) with priorities; there are "important customers" that can be served with the first available agent, It means a preemptive behavior. (iv)The system capacity is limited by the available space where the customers waiting have to be served. There is a forced balking, because the customer that arrives when there is no space waits outdoors (which for purpose of this work is out of the system). (v) The number of serves is designed with historical data of capacity; They can be from one to twelve depending on the characteristics of the service center. These servers, agents or operators are parallel distributed and work independently from each other. (vi) The stage of service is unique; it means that after the customer has been served, he leaves the facilities. With these characteristics described above we get the relevant data to run our model.

\section{Results and discussions}

Using a correlations analysis between the TMO (independent variable) and the real SL (dependent variables) for every office (location), we get the values of correlation coefficients which are shown in table 3 . The sign of the value shows a positive or negative correlation.

Table 3: Results of correlation between Real TMO (independent variable) and Real LS (Dependent variable)

\begin{tabular}{lccccc}
\hline Offices & $\begin{array}{c}\text { Correlation } \\
\text { Coefficient } \\
(\mathbf{r})\end{array}$ & $\begin{array}{c}\text { Validate of } \\
\text { Hypothesis } \\
(\mathrm{H} 1)\end{array}$ & $\begin{array}{c}\text { Number } \\
\text { of } \\
\text { Operators }\end{array}$ & $\begin{array}{c}\text { Average } \\
\text { TMO }\end{array}$ & $\begin{array}{c}\text { Standard } \\
\text { Deviation }\end{array}$ \\
\hline San Miguel & -0.28116 & yes & 2.6 & 8.36 & 1.45 \\
Megaplaza & 0.19639 & no & 3 & 11.49 & 1.20 \\
Lince & -0.04039 & yes & 2.9 & 12.96 & 1.86 \\
Juan de Arona & 0.38730 & no & 6 & 16.78 & 1.40 \\
Camino Real1 & -0.02511 & yes & 4.5 & 12.92 & 1.75 \\
Jr. de la Unión & 0.11578 & no & 3.3 & 8.50 & 0.50 \\
Miraflores & -0.07338 & yes & 2.7 & 10.00 & 1.63 \\
San Juan de Miraflores & -0.13930 & yes & 1 & 8.50 & 0.90 \\
San Borja & 0.34588 & no & 8.9 & 15.65 & 1.20 \\
\hline p-values $<0.05$ & \multicolumn{7}{r}{} \\
p-vlue $<0.1$ & \multicolumn{7}{r}{} \\
\hline
\end{tabular}



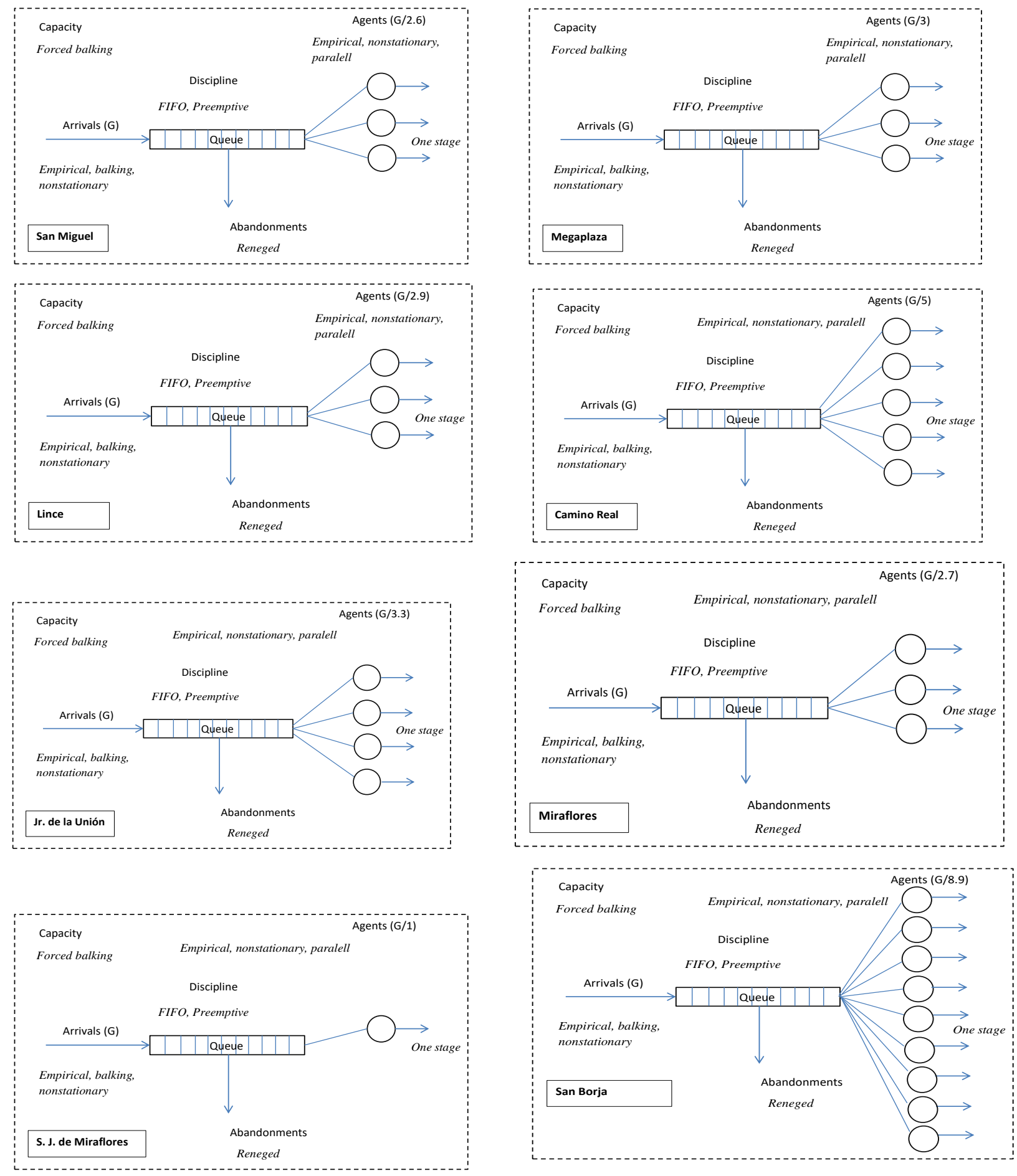

Figure 1: Characteristics of the model of queue system of technical assistance centers of a cellphone company in Lima, Peru. 
operators is high, the positive correlation between TMO and SL become strong.

Table 4: Results of correlation ( $r$ ) between TMO (independent variable) and Simulated SL (Dependent variable) for each technical assistance center.

\begin{tabular}{lccr}
\hline Offices & $\begin{array}{c}\text { Correlation } \\
\text { Coefficient } \\
(\mathbf{r})\end{array}$ & $\begin{array}{c}\text { Validate of } \\
\text { Hypothesis } \\
(\mathrm{H} 1)\end{array}$ & $\begin{array}{c}\text { Number } \\
\text { of } \\
\text { Operators }\end{array}$ \\
\hline San Miguel & -0.66818 & si & 2.6 \\
Megaplaza & -0.09330 & si & 3 \\
Lince & -0.20237 & si & 2.9 \\
Juan de & & & \\
Arona & 0.18849 & no & 6 \\
Camino Real & -0.11266 & si & 4.5 \\
Jr. de la & & & \\
Union & -0.63394 & si & 3.3 \\
Miraflores & 0.17721 & no & 2.7 \\
San Juan de & & & 1 \\
Miraflores & -0.08382 & si & 8.9 \\
San Borja & 0.33276 & no & \\
\hline
\end{tabular}

p-values $<0.05$

Using the simulated SL data in the offices with numbers of operators between 3 and 5 such as Camino Real, San Juan de Miraflores, Jr. de la Unión, and Megaplaza the results give us evidence to support the Hypothesis (at 95\% Confidence Level). There is a threshold where hypothesis is accomplished, but with a very little value of the $r$. For example, with San Juan de Miraflores the Correlation coefficient $r=-0.0838$ a very little value that support the Hypothesis (see Table 4). Then, when the number of operators is higher than 6 , the correlation is positive (with $95 \%$ confidence level). And the degree of correlation with operators less than 6 is weak.

Figures 2, 3, 4 and 5, show us the line of regression of some technical attention points or offices (San Juan de Miraflores and San Borja) of real and simulated data. The slopes show the negative or positive relationship between TMO and real and simulated LS. $r$ is the coefficient of correlation and $c$ is the number of operators or agents.

\section{Conclusions}

For a Technical Assistance Service of a Cellphone company in Lima, Peru using real data registered by 5 months and simulated data for the same period, from 9 locations geographically distributed throughout the city of Lima. We can conclude that the relationship between the Time Mean Operation and Service Level is negative. The higher the value of TMO, the lesser the value of SL if the number of operators is less than 3 . This relationship keeps negative if the analyzed data comes from the simulation model, but with number of operators less than 6 . These conclusions are at $95 \%$ of statistical confidence level.

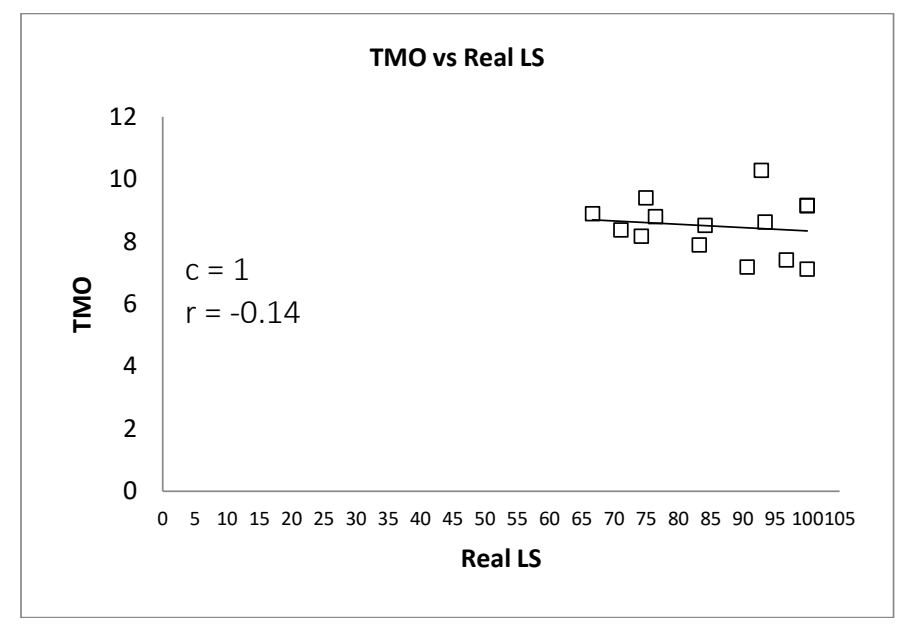

Figure 2:TMO vs. Real LS. From the plot of data of San Juan de Miraflores we can see the negative correlation of Operation Mean Time (TMO) and Service Level (LS) with real values. The data of $L S$ is scattered from 65 to $100 \%$.

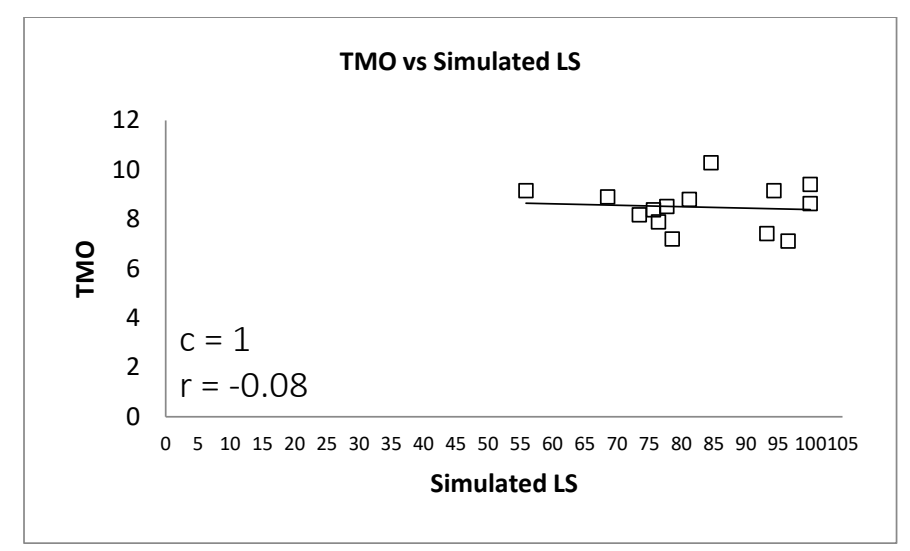

Figure 3:TMO vs. Simulated LS. From the plot of data of San Juan de Miraflores. we can see the slightly negative correlation of Operation Mean Time (TMO) and Real Level of Service (LS) with simulated values. The data of LS is scattered from 55 to $100 \%$. 


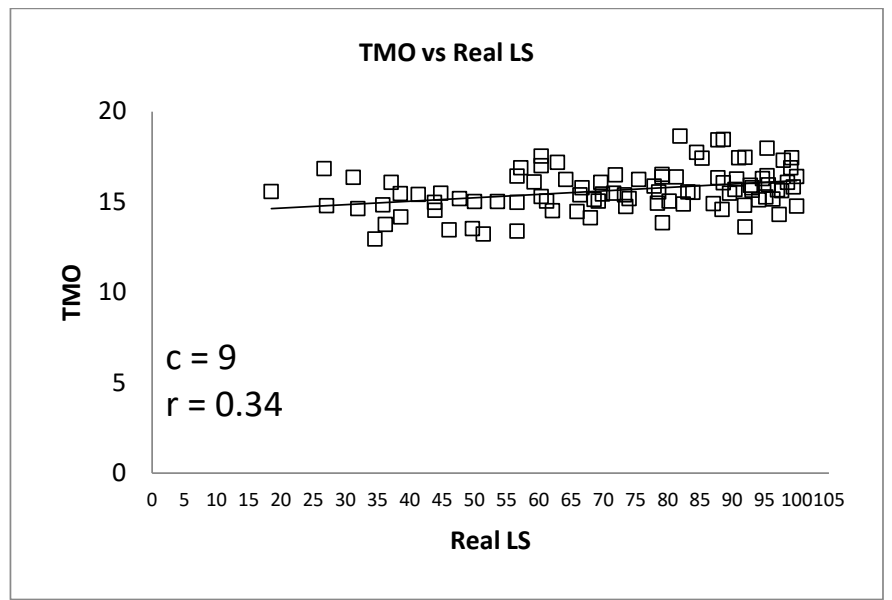

Figure 4:TMO vs. Real LS. From the plot of data of San Borja we can see the positive correlation of Operation Mean Time (TMO) and Service Level (LS) with real values. The data of $L S$ is scattered from 20 to $100 \%$.

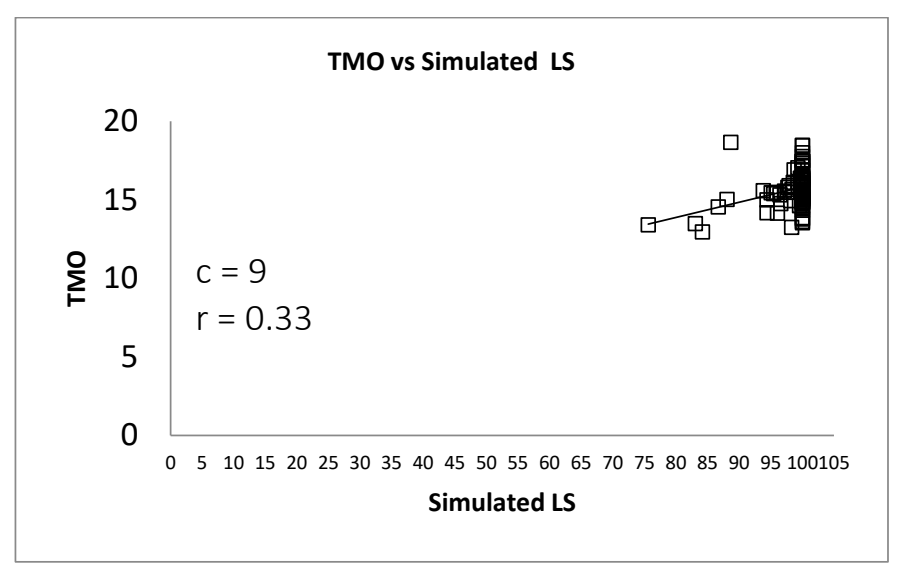

Figure 5:TMO vs. Simulated LS. From the plot of data of San Borja we can see the positive correlation of Operation Mean Time (TMO) and Service Level (LS) with simulated values. The data of $L S$ is scattered from 75 to $100 \%$.

the model of technical assistance centers of a cellphone company in Lima, Peru is very complex to apply directly the mathematical formulas of Queuing Theory. We need to consider real facts that break down the traditional assumptions of exponential or Poisson distribution for arrivals and Service Times. In our study case it was necessary to work with empirical probabilistic distribution (because of the non-stationary arrivals) and preemptive behavior of the customers.

The simulation helps to analyze real system through the modeling which was built with the real considerations with notorious advantages over the mathematical formulas.

\subsection{Future research}

Operators do not have Independent Times. They can vary their attention speed according to the length of the queue although this is not completely decisive for negative correlations between the TMO and the LS. However, the dependency between their times were observed between one office operators, it means that TMO of one agent is influenced by the other agent, and this is not due to the lack of knowledge or experience, but for many other elements that combine the nature of service. If an operator does not have a solution or if he does not remember how to manage a technical problem, he will ask to his adjacent or nearby colleague, busy or not, to find a solution for the customer's problem, its implies that two agents are serving to two customers at the same time. Then, under this behavior it becomes necessary to investigate the degree of dependence between the Time Mean Operation, the number of operators or servers and the measurements of performance as the Service Level with the aforementioned considerations. These issues are important for supervisors or managers that need to improve his operations, for example, if a supervisor knew that there is dependency among the agents, he would consider setting adjacent operators with superior knowledge or experience to improve the Time Mean Operation in all the offices. These require, however, further research and development in the queuing theory.

\section{Acknowledges}

We are acknowldeged to Alex Ruiz PhD. for his valuable contributions and for lending us valuable material to carry out the present study.

\section{Referencias}

[1] X. Guo, and K. Yan, "Estimation of obsolete cellular phones generation: A case study of China," Science of Total Environment, vol. 575 , pp. 321-329, January 2017.

[2] E. Thiébaud, L. M. Hilty, M. Schluep, and M. Faulstich, "Use, storage, and disposal of electronic equipment in Switzerland," Environmental science \& technology, vol. 51, pp. 4494-4502, April 2017.

[3] R. Zhou, X. Wang, Y. Shi, R. Zhang, and L. Zhang. "Measuring e-service quality and its importance to customer satisfaction and loyalty: An empirical study in a telecom 
setting," Electron Commer Res, vol. 19, pp. 477- 499, September 2019.

[4] R. Ibrahim, H. Ye, P. L'Elecuyer, and H. Sheen, "Modeling and forecasting call center arrivals: A literature survey and a case study," International Journal of Forecasting, vol. 32, pp. 865-874, July 2016.

[5] M. N. Uddin, M. Rashid, and M. Mostafa, "Automated queue management system," Global Journal of Management and Business Research, vol. 16, no. 1, pp. 5158, 2016.

[6] W.J. Stewart. Probability, Markov Chains, Queues, and Simulation: The mathematical basis of Performance Modeling. Princeton: Princeton University Press, 2009.

[7] L. Liang. Staffing Level Analysis for a Product Inspection Process: Applying Simulation Techniques and Queuing Theory to a Real World Problem. California: Lambert Academic Publishing, 2010.

[8] T. C. Xian, C. W. Hong, and N.N. Hawari, "Modeling and simulation of queuing system for customer service improvement: A case study," AIP Conference Proceedings, vol. 1782, no. 1, October 2016.
[9] J. P. Garcia. (2021, Octubre 1). Aplicando Teoría de colas en Dirección de Operaciones [Online]. Available: http://personales.upv.es/jpgarcia/ LinkedDocuments/Teoriadecolasdoc.pdf

[10] R. Chase, F. R. Jacobs, and N. Aquilano. Operations Management For Competitive Advantage. New York: McGraw-Hill/Irwin, 2005.

[11] J. Artalejo, A. Economu, and M. LopezHerrero, "Algorithmic Analysis of the Maximum Queue Length in a Busy Period for the $M / M / c$ Retrial Queue". Journal on Computing, Vol. 19, no. 1, pp. 121-126, 2007.

[12] D. P. Gaver, "The influence of servicing times in queuing processes," Journal of the Operations Research Society of America, Vol. 2, no. 2, pp. 139-149. 